\title{
Collaborative Governance for Sustainable Development in Indonesia's Fisheries and Marine Resources Governance
}

\author{
Gusjoy Setiawan ${ }^{1}$, Faisal Santiago ${ }^{2}$ \\ Universitas Borobudur Jakarta ${ }^{1,2}$ \\ \{gusunbor@gmail.com¹, faisalsantiago@borobudur.ac.id²
}

\begin{abstract}
Towards the era of society 5.0 all institutional elements must prepare themselves for tighter competition due to the absence of barriers between countries in interacting and the ease of conducting cooperation between countries. The Ministry of Maritime Affairs and Fisheries as a state institution authorized to manage fisheries and marine resources must be able to improve the management of fisheries resources, one of which is by applying the principles in sustainable development goals. By conducting partnerships between the government and the private sector, the government with NGOs and the government and public actors will result in sustainable management of fisheries and marine resources. The methodology in this study is a qualitative study using interviews and FGD with experts as primary data and literature material such as policy documents, conference results as secondary data. In managing fisheries and marine resources needing collaborative management and sustainable management, he proposes five factors to explain the promising development of collaborative governance for sustainable development in Indonesia: political leadership, discourse, domestic expertise, institutional density and international cooperation. This paper is also intended to analyze the involvement of the Indonesian government in this case the Ministry of Marine Affairs and Fisheries which is increasing for sustainable development with the concept of collaborative governance.
\end{abstract}

Keywords: Collaborative Governance; SDGs; Governance; Green Development

\section{Introduction}

The era of society or so-called society 5.0 challenges and obstacles between nations is not easy. Therefore, every institution must collaborate to solve problems by discussing sharing experiences to solve a problem. Sustainable Development was defined in 1987 by the Brundtland Report as "development that meets the needs of the present generation without compromising the ability of future generations to meet their own needs" (UN, 1987), seeking social happiness based on the environment efficient economy. Through primary school age, the human element has always been his main interest, targeted by the MDGs, to become one 
of the three primary capitals, and was highly considered during discussions and workshops for the post-2015 SDGs (ESCWA, 2013).

Sustainable Development Goals (SDG's) in the field of marine ecosystems are in item 14 which contains about improving and maintaining and preserving marine ecosystems. The challenge that must be faced by Indonesia concerning item 14 of the SDGs is the imbalance of management and the lack of protection of marine and coastal ecosystems in several areas which of course need serious handling from the government. The very high level of illegal fishing has also become a polemic, next is the imbalance of marine infrastructure which of course will have an impact on inequality in many ways.

Meanwhile, when we talk about collaboration which means working together or working together with other people. This implies individual, group, or organizational actors working together in an effort. Participants 'work together' with others on terms and conditions which, as we know, can vary widely. The word 'collaboration' originally came into use in the 19th century as industrialization developed, more complex organizations emerged and the division of labor and tasks increased. These are the fundamental norms of utilitarianism, social liberalism, collectivism, mutual aid, and later, scientific management and the organizational theory of human relations. The progress targets of one goal of the Sustainable Development Goals (SDGs) include (Source: UN Secretary General Report):

a. More than half of the world's population lives in cities. By 2030, it is projected that 6 out of 10 people will be urban residents. Despite the many planning challenges, well-managed cities and other human settlements can be incubators for innovation and ingenuity and key drivers of sustainable development.

b. However, as more people migrate to cities in search of a better life and the urban population grows, the housing problem intensifies. Already in 2014, 30 percent of the urban population lived in slum-like conditions; in sub-Saharan Africa, it is 55 percent, the highest of any region. Globally, more than 880 million people lived in slums in 2014. This estimate does not include people in inadequate or inaccessible housing (defined as a cost of more than 30 percent of total monthly household income).

c. As population growth exceeds available land, cities develop well beyond their formal administrative boundaries. This urban sprawl can be seen in many cities around the world, and not only in developing areas. From 2000 to 2015, the ratio of land consumption to population growth rates in East Asia and Oceania was the highest in the world, with the second developed region. Other regions, such as Southeast Asia and Latin America, and the Caribbean, saw a decline in the indicator over the same period. Unfortunately, a low score for this ratio is not necessarily an indication that the urban population is doing well, as it can indicate the prevalence of dense slum areas. The unplanned spread of cities undermines another determinant of sustainable development. For example, for every 10 percent increase in spread, there is a 5.7 percent increase in carbon dioxide emissions per capita and a 9.6 percent increase in harmful pollution per capita. This illustrates the important linkages between goals and targets

d. Likewise, managing solid waste is often problematic in densely populated areas. In fact, in many developing regions, less than half of solid waste is disposed of safely. As per capita waste generation continues to increase, the safe collection and disposal of solid waste will continue to require serious attention.

e. Urban air pollution also challenges cities around the world, causing disease and millions of premature deaths every year. In 2014, about half of the global urban population was exposed to air pollution levels at least 2.5 times higher than the maximum standards set by the World Health Organization. 
f. The search for sustainable and coordinated urban development begins with national policies and regional development plans. As of 2015, 142 countries have national urban policies or are under development. These countries are home to 75 percent of the world's urban population.

When talking about sustainable development in Indonesia, we must see that the vision of Nawa Cita conveyed by the President of the Republic of Indonesia has a strategic side to national development even though Nawa Cita and the SDGs come from different perspectives. Nawa Cita begins with the President's vision of national sovereignty in the political, economic, and cultural fields, which originates from the assessment that the nation is facing three problems: (a) an inability to ensure the safety of all citizens, (b) poverty, inequality, environmental degradation, and overexploitation of natural resources, and (c) intolerance and a crisis of national character. Meanwhile, the SDGs see poverty, inequality and environmental degradation, and overexploitation of natural resources as global problems that all countries need to address in the next 15 years. (Harry, 2015)

Besides, Nawa Cita, as reflected in the RPJMN, includes both sectoral and regional (spatial) objectives, while the SDGs focus on sectoral issues. Differences also arise in the categorization of issues between global and national agendas. For example, good governance in Nawa Cita and RPJMN is considered a specific target to be achieved and an overall theme for mainstreaming, whereas in good governance the SDGs are goals with specific targets to be achieved. Sustainable development in Indonesia has two indicators, the first is an environmental indicator and the second is a socioeconomic indicator. As two indicators (BPS: 2016) Talking about sustainable development in MPAs, the two sectors that are indicators of the SDGs have been well done by the government. Both from the environmental and socioeconomic side of society. As the ministry in charge of marine and fisheries governance in Indonesia, KKP can implement public services that facilitate service beneficiaries very well. Initiating communication between fishermen and community actors in the KP industry then becomes a new synergy in KP governance in Indonesia. Several times KP Minister paid a visit to the area to ensure synergy goes well.

\section{Methodology}

The methodology in this paper uses descriptive qualitative using interviews and FGDs with experts as primary data and literature or research libraries such as policy documents, we use relevant conference results as secondary data. Based on the data found and collected in the field, the researchers then analyzed the data using interactive models from Miles, Huberman, and Saldana. Data analysis consists of four streams of activity, namely: data collection, data condensation, data presentation, and concluding. The purpose of using interactive data model analysis is to describe it systematically, factually, and accurately. This methodology is based not on a probability sample involving random selection but on a non-probability sample of experts who can be considered a subgroup of purposive sampling. The women and men experts interviewed had different ages, institutional affiliations, and disciplinary backgrounds.

\section{Result and Discussion}

\subsection{Collaborative Governance Concept}


Managing the maritime sector, in this case, fisheries and marine affairs requires a large and mutually reinforcing instrument between the government and the community. According to Emerson (2011), collaborative governance is the process and structure of public policymaking and governance by involving the public, private sector, NGOs, from various existing institutions and levels to determine common goals that are difficult to formulate on their own. (Eko Priyo Purnomo \& Rendra setyadiharja, 2018). Meanwhile, according to Ansel \& Gash (2007), Collaborative governance brings together public and private stakeholders in a collective forum with public institutions to engage in consensus-oriented decision making. Collaborative governance arrangements have the potential to harness knowledge from a larger variety of sources and provide people and institutions with wider access. In doing so, they provide an opportunity to increase the legitimacy of policy and project implementation. (Ansel \& Gash dalam Kencono, Dewi Sekar \& EE, Supriyanto 2017).

\subsubsection{Collaboration in the Meaning of Process}

Collaboration in the meaning of process is a series of activities or a series of activities or an institutional way of managing. Several institutions are involved in both government agencies, non-government organizations, including the community and several communities in it. Such involvement is usually following the portion of the interests and goals of each Institution. The portions of this relationship are not always the same, some are only involved in a few activities and may be involved as a whole as well. Understanding collaboration in the sense of a process is the purpose of this article.

In this context, the institutions or agencies involved in the cooperation come from government agencies, namely several ministries related to maritime affairs and fisheries, and several ministries in other fields, including the police agency, the Navy, state-owned enterprises that do business in the marine and fisheries sector, and the community or associations such as fisher associations, and others from academics, university representatives, to experts in the field of maritime affairs and fisheries, as well as non-governmental organizations whose activities are in the field of fisheries, and marine and fisheries observers. All of these institutions are included in formal forums that are deliberately held to coordinate between agencies, provinces, and districts/cities.

\subsubsection{Collaboration in a Normative Understanding}

Kolaborasi dalam pengertian ini terkait dengan tujuan atau aspirasi pemerintah dalam berinteraksi dengan mitra. Tata kelola kolaboratif, dalam hal ini, tidak hanya lembaga formal tetapi juga dapat menjadi cara berperilaku (perilaku non-pemerintah) dari lembaga yang lebih besar dalam melibatkan diri dalam manajemen publik dalam suatu periode.

Collaborative governance is one of the paradigms in public administration. The term governance itself seems to replace the term government in the Old Public Administration paradigm and the new New Public Management paradigm. The shift in terms aims to democratize public administration, namely, the Government places more emphasis on government institutions, while the Government emphasizes the involvement of NonGovernment Organizations (NGOs), interest groups, and the public. According to Richard and Smith in Syafri (2012: 196), the concept of governance takes into account all actors and policy areas outside the "core government/executive" involved in the policy-making process.

According to Ansell and Gash (2007), collaborative governance is a process of governance that directly involves stakeholders outside the country, is consensus-oriented, and is 
deliberative in the collective decision-making process, which has the goal of creating or implementing public policies and programs. In this case, the emphasis is on achieving a level of consensus among stakeholders. O'Leary, Bingham, and, Gerard (2006) in Emerson define governance as a process that influences decisions and actions in the private, public, and public sectors. More specifically, governance is a set of coordination and monitoring activities that enable the viability of partnerships or collaborative institutions (Bryson, Crosby, and Stone in EmersonBroader than Ansell's proposed definition of Agrawan and Lemos (2007) in Emerson, the collaborative government includes multi-partner governance that includes partnerships between countries, the private sector, civil society, and the incorporation of government with additional rules such as government with private and private sectors, institutions, and comanagement of regimes.

The Government does not only emphasize the involvement of Non-Governmental Organizations. However, this concept contains a complex meaning which is not only the involvement of public institutions in the formulation and implementation of policies but the relationship of various organizations to implement public goals. (Keban, 2004: 121-122). From the several definitions that have been stated above, it can be concluded that collaborative governance is a way of managing multi-partner governance that involves various stakeholders, either directly or indirectly, is consensus-oriented, and there is "deliberation" in the collective decision-making process, but governance collaborative management is not just a formal institution but can be a way of behaving.

Collaboration between the government and the political will of the (regional) government to expand internal decentralization and to develop cooperation with the public and private sector will have a direct or indirect impact on the format of public service institutions. This is logical, given that any reduction in the role/function of the government on the one hand, and strengthening of the role/function of the private sector or society on the other, automatically demands institutional restructuring. Thus, the institutional or conventional apparatus that we know so far based on articles 60 to 68 of Law Number 22 of 1999, may become less relevant to the real demands on the ground.

\subsubsection{Collaboration Governance Concept}

The SDGs currently need to be translated and integrated into national and even regional development agendas. In the case of Indonesia, it raises questions about the extent to which the convergence of the Nawa Cita, RPJMN, and SDGs occurs and how the new global goals can support Indonesia's national development. This paper analyzes whether this convergence exists. This paper seeks to examine the extent to which the SDGs have been reflected in the national development agenda and identify opportunities to fully integrate them if needed. This is done in more detail in the four main focus areas of UNDP and the Government of Indonesia, which are the gap, the environment and energy, governance, and global partnerships. In order not to be technical, this paper does not review the global and national agendas at the indicator level but the objective level. (Harry, 2015).

Collaborative practices replace hierarchical approaches with approaches that encourage interaction between peers (government and society). The hierarchical model emphasizes oneway communication and has a dominant character. Whereas the collaborative practice model emphasizes two-way communication, but still, places one leader in the main government position. The cyclical model emphasizes continuity, reciprocity of conditions, and no one dominates. 
Why collaborative governance is needed, the reasons are (a) building understanding through sharing ideas and information between various parties, providing mechanisms to resolve uncertainties, (b) building effective decision-making mechanisms through processes that focus on problem cooperation and building support; (c) produce effective work tools through cross-border coordination, co-management, and mobilization of ideas, and (d) develop multi-stakeholder capacities to face future challenges (Kencono, Dewi Sekar \& EE, 2017). The formation of collaborative management can be started from the processes of cooperation, partnership, and finally collaboration. Achieve equality in collaboration requires a very long time and if collaboration has been achieved, it is hoped that self-governance will be achieved.

\subsubsection{Potential for Collaborative Governance in Marine and Fisheries Governance}

The point of collaborative governance in marine and fisheries governance has, among other things, the policies carried out by the Ministry of Marine Affairs and Fisheries and then implementing collaborative governance based on sustainable development.

Sustainable development related to marine and fisheries governance is at point 14. The 14th Sustainable Development Goals are related to life underwater and coastal areas which have the aim of improving and maintaining the quality of the carrying capacity and the sustainability of the functions of marine ecosystems, and increasing fishermen's income and also coastal communities. As stated on the SDG's UN website as follows: "Combating Human Right Abused in Fishing Industry".

The statement above explains that the Indonesian government through the Ministry of Maritime Affairs and Fisheries is committed to protecting the human rights of workers in the fishing industry and providing them with a decent and healthy work environment, and the opportunity to improve their economy. This commitment is in the SDG indicator 14 related to marine and fisheries as follows:

\begin{tabular}{lll}
\hline & Indicator & Type of Commitment \\
\hline By 2020, prohibit certain forms of fisheries subsidies that contribute to & - \\
overcapacity and overfishing, remove subsidies that contribute to & \\
illegal, unreported, and unregulated fishing, and refrain from & \\
introducing such new subsidies, recognizing that special and & \\
differential treatment is necessary. appropriate and effective for & \\
developing and least developed countries should be an integral part of & \\
the World Trade Organization fisheries subsidy negotiations (14.6) & \\
Provide small-scale artisanal fishermen with access to marine resources & $\begin{array}{l}\text { Legal/policy/institutional } \\
\text { and markets (14.b) }\end{array}$ \\
\hline
\end{tabular}

Another potential that must be followed up by the Ministry of Maritime Affairs and Fisheries is the readiness of the Indonesian people as the world's maritime axis. This potential requires good collaborative governance between ministries/agencies, local governments, and non-governmental organizations. This cross-sector collaboration considering that personalities in the maritime area are very complex. Although KKP is not the main actor in Indonesia's maritime axis project in the world, it is the key of the Indonesian maritime data center, together with Kominfo and BMKG, which will determine the success of the project. The idea of a world maritime axis is a form of elaboration by President Joko Widodo at the Indonesia Summit in Beijing and Nanjing Port, on 8-12 November 2014, as well as the decision of the ASEAN Summit in Naypyidaw, Myanmar, on 13 November 2014, by presenting 5 elements, 
namely: (a) maritime culture; (b) maritime economy; (c) maritime connectivity; (d) maritime resilience; (e) maritime diplomacy.

\subsubsection{Limitations of Collaborative Governance}

Government collaboration becomes an idea to achieve common goals by involving work processes and working together in achieving common goals. The main motivation is to achieve collective results that would not have been possible if each party worked independently. As in cooperation, the parties collaborate in the hope of achieving innovative results, breakthroughs, special and satisfying in this case collective achievement. The implementation of government collaboration with stakeholders certainly has considerable obstacles, although it has a common goal, sometimes collaboration has different interests.

Collaboration does not just happen, like operating in an institutional hierarchy, collaboration must be managed albeit in different ways. In today's economic development, many areas of special policies which are economic development, resources for critical policymakers in the field of finance, information, labor, knowledge of legal authorities, and expertise are not in an exclusive condition in public organizations but at other levels of government, regencies, water districts, utilities, chambers of commerce, and development companies. The context of development between cities strategically and collaboratively to achieve its political and economic goals. Of course, this is an opportunity that can be taken advantage of by some but not all Institutions (Agranoff \& McGuire, 2003).

According to Gray, there are 7 (seven) collaboration obstacles, including:

a. Commitment goes against collaboration

b. A history of hostility based on ideological differences for a long time

c. A condition in which the policy does not pay attention to the allocation of resources

d. Differences in risk perceptions

e. Complexity is technical

f. Institutional culture and politics / no legitimacy

g. Unilateral action (one party has power in unilateral actions.

\subsection{Supporting Factors for Governance Cooperation that Support Sustainable Development}

\subsubsection{Political Leadership}

Political leadership is very vital in public organizations, considering that leaders have a managerial role that can determine the direction of an institution's policies towards the vision and mission outlined by the president. The concept of leadership is sufficient to become a barometer of a public institution in carrying out its main duties and functions within the authority that has been determined by law.

The Ministry of Marine and Fisheries Affairs has the authority in the marine and fisheries sector. As a state institution, KKP has a very strong commitment not only in the form of discourse but also quite innovative actions and making breakthroughs in the management of marine and fisheries resources.

Although only about 6 million of the total population of Indonesia are directly involved in the fishery and marine cultivation industry, the dependence of the Indonesian people on the sea is still very high. Therefore, the need to protect Indonesia's marine ecosystem is very 
important. The Indonesian sea is home to more than 20 percent or 2.2 million hectares of the world's mangrove forests.

The leadership in the MMAF is contextual to the authority given to the MMAF to protect marine ecosystems, fisheries, and coastal areas. There are 7 (seven) pillars that become Indonesian maritime policies, including a) defense, security, law enforcement, and safety at sea; b) Marine governance and institutions; c) Economy, infrastructure, and welfare improvement; d) Management of marine space and protection of the marine environment; e) Maritime culture; f) Maritime diplomacy; g) management of marine resources and human resource development. Of the seven pillars, it certainly requires collaboration in governance with ministries / other state institutions to support the success which is the common goal.

To see this collaboration model, the author made a table related to the collaboration between KKP and Ministries / Agencies as well as NGOs as follows:

\begin{tabular}{|c|c|c|c|}
\hline No & Marine Policy & Collaborative Governance & Information \\
\hline 1. & $\begin{array}{l}\text { Defense, security, law } \\
\text { enforcement and safety at } \\
\text { sea }\end{array}$ & $\begin{array}{ll}\text { a. } & \text { TNI-AL } \\
\text { b. } & \text { POLRI/POLAIR } \\
\text { c. } & \text { Kemenkumham } \\
\text { d. Kemenkeu/Beacukai } \\
\text { e. } \\
\text { BAKAMLA }\end{array}$ & \\
\hline 2. & $\begin{array}{l}\text { Marine governance and } \\
\text { institutions }\end{array}$ & $\begin{array}{l}\text { a. Ministry of Maritime Affairs } \\
\text { b. Ministry of Administrative and } \\
\text { Bureaucratic Reform }\end{array}$ & \\
\hline 3. & $\begin{array}{l}\text { Economy, infrastructure } \\
\text { and welfare improvement }\end{array}$ & $\begin{array}{l}\text { a. Coordinating Ministry for the } \\
\text { Economy Affairs } \\
\text { b. Ministry of Finance Indonesia } \\
\text { c. Ministry of Social Affairs } \\
\text { d. NGO/Swasta (CSR) }\end{array}$ & \\
\hline 4. & $\begin{array}{l}\text { Management of marine } \\
\text { space and protection of the } \\
\text { marine environment }\end{array}$ & $\begin{array}{l}\text { a. Indonesian Maritime Security } \\
\text { AgencyIndonesian }\end{array}$ & \\
\hline 5. & Maritime culture & $\begin{array}{l}\text { a. Ministry of Environment } \\
\text { b. Fishing Community/NGO }\end{array}$ & \\
\hline 6. & Maritime diplomacy & $\begin{array}{l}\text { a. Ministry of Foreign Affairs } \\
\text { b. Ministry of Law and Human } \\
\text { Rights }\end{array}$ & \\
\hline 7. & $\begin{array}{l}\text { Management of marine } \\
\text { resources and human } \\
\text { resource development }\end{array}$ & $\begin{array}{l}\text { a. Ministry of Manpower } \\
\text { b. Indonesian Institute of Science } \\
\text { (LIPI) } \\
\text { c. Ministry }\end{array}$ & \\
\hline
\end{tabular}

\subsubsection{Discourse}

A policy of political leadership that is quite successful will certainly lead to a discourse that the CTF will easily collaborate with other sectors in realizing sustainable development. Policies such as the sinking of illegal fishing vessels, the prohibition of fishing using trawl, ease of investment in marine and fisheries, the government's commitment to managing marine and fisheries under the sustainable development agenda, and other policies.

Although the policies implemented by the CTF have received mixed responses from international parties, the CTF certainly has a strategic plan and a road map related to its policies. In addition to institutional policies, the KKP also needs to synergize with central 
government policies that intersect with the KKP's work areas such as the construction of a sea highway, and the discourse of Indonesia as a world maritime axis which of course needs to be taken seriously. In this paper, the author does not want to discuss too far the synergy between the CTF and the national policies related to maritime affairs but tries to implement several KKP policies in the strategic plan. The following are the KKP's main policies, among others (Renstra KKP, 2019):

a) Building sovereignty that is able to sustain economic independence in managing marine and fishery resources, the strategies are, among others:

1. Combating IUU Fishing. The operational steps taken are (a) surveillance operations at sea with integrated technology and surveillance modes, (b) handling violations and law enforcement at sea by imposing strict sanctions and providing a deterrent effect for perpetrators and corporations that commit violations, (c) drowning illegal lasing, (d) strengthening the Task Force to eradicate Illegal fishing, (e) strengthening regional and international cooperation, (f) consistently implementing Monitoring, Control, and Surveillance (MCS).

2. Improve the integrated SDKP monitoring system. Operational steps that will be carried out are (a) strengthening of supervision and infrastructure facilities (monitoring vessels for other supporting facilities), (b) strengthening human resources and supervisory institutions, (c) monitoring the compliance of marine and fisheries business actors, (d) enforcement and handling of human rights violations in the field of KP, (e) development of a control center (pusdal) for KP, (f) supervision of SDKP by the Provincial DKP, and delegation to districts/cities through Pokmaswas.

3. Developing a fish quarantine system, fostering quality, and increasing the safety of fishery products. Operational steps that will be taken are (a) strengthening the fish quarantine system, (b) building Joint/integrated/gateway control units in border areas, (c) certification of quality and safety of fishery products, (d) controlling biological agents that are protected, prohibited and invasive, (e) standardization and compliance, (f) implementation of a quality assurance system.

b) Applying the principles of responsible, competitive and sustainable marine and fisheries resource management.

1. Optimizing the use of marine and coastal space. Operational steps that will be carried out are (a) planning for national marine space and strategic areas, (b) regulating the use of marine and coastal space, (c) regulating marine services (marine tourism, BMKT, etc.).

2. Managing fish resources in 11 Fisheries Management Areas of the Republic of Indonesia (WPPNRI). Operational steps that will be carried out are (a) Establishment and operationalization of the WPPNRI management agency, (b) Application of fishing quotas, (c) Limiting the size of fishing vessels, (d) Development of national fishing fleets, (e) Regulating fishing gear (API) ) environmentally friendly, (f) Sowing seeds in the sea (fish/crab/lobster / etc.), (g) Management of fishery ports and portability, (h) Implementation of the Port State Measurement Agreement (PSMA).

3. Controlling capture fisheries resources. Operational steps that will be carried out are (a) Improving the web-based (online) licensing system and strengthening the database, (b) Increasing PNBP from Fishery SDA.

4. Managing the utilization of mainland public waters (PUD). Operational steps that will be carried out are (a) spatial planning in PUD, (b) Sowing endemic fish seeds in PUD, (c) Arrangement for cage cultivation in PUD, (d) Establishment of PUD management institutions. 
5. Build independence in aquaculture. Operational steps that will be carried out are (a) Provision of superior broodstock, quality fish seeds, and tissue culture seaweed seeds, including strengthening of Local Seed Centers and Community Seed Units, (b) Cultivating seaweed, (c) Cultivating freshwater and brackish water fish., (d) Aquaculture/mariculture, (e) Independent feed and fish medicine, (f) Strengthening of cultivation infrastructure and facilities, (g) Development of cultivation areas, (h) Certification of land for fish cultivators, (i) Regulation of transport of live fish.

6. Improve the logistic system of fishery products. Operational steps to be carried out are (a) Provision of Fish Processing Units and Integrated Cold Storage, (b) Provision of storage systems for marine and fishery products (including salt), (c) Provision of salt transportation infrastructure, (d) Cold Chain Systems (Cold Chain System).

7. Improve the quality, diversification, and market access of marine and fishery products. Operational steps that will be carried out are (a) Increasing the quality and safety of fishery products, (b) Standardizing marine and fishery products, (c) Diversifying marine and fishery products, (d) Developing seaweed and fishery products industries, (e) Increasing production and the quality of people's salt becomes industrial salt, (f) Promotion of marine and fishery products, (g) Revitalization of Traditional Markets and development of clean fish markets, (h) market intelligence, (i) market intelligence, (j) Monitoring the Traceability of KP Products.

8. To rehabilitate the ecosystem and protect the marine environment. Operational steps that will be carried out are (a) Rehabilitation of coastal areas (green belt development) and the marine environment, (b) Arrangement of marine conservation areas, (3) Protection and preservation of biodiversity.

9. Build the independence of small islands. Operational steps that will be carried out are (a) Development of Integrated Marine and Fisheries Centers, (b) Promotion and investment of utilization of small islands, (c) Certification of land rights for small/outermost islands, (d) provision of infrastructure facilities and infrastructure on the coast and small islands.

c) Increase empowerment and independence in maintaining the sustainability of marine and fisheries businesses.

1. Providing protection to fishermen, fish cultivators, and salt farmers. Operational steps that will be carried out are (a) Insurance for fishermen and fish cultivators, (b) Facilitation for famine/natural disaster assistance, (c) Strengthening the socio-culture of indigenous peoples.

2. Realizing the main actors who are independent, competent, aware, and concerned about the sustainability of marine and fisheries resources. The operational steps are: (a). Increasing micro to small and small to medium scale businesses through assistance; (b). Facilitating banking access and the formation of microfinance institutions or cooperatives; (c). Facilitation of institutions or groups with legal entities; (d). Utilization of information technology to expand and facilitate access to extension information through cyber extensions.

3. Increase marine and fisheries business and investment. The operational steps that will be carried out are (a) Community business development, (b) Increasing investment in $\mathrm{KP}$, (c) Optimizing the role of LPUMKP.

4. Increase the competence of the KP community through education, training, and counseling. Operational steps that will be carried out are (a) Development of Marine and Fisheries Polytechnic; (b). Providing greater opportunities for sons/daughters of marine and fisheries main actors to obtain an education in marine and fisheries 
education units; (c). Improving the quality of learning with the Teaching Factory approach in the marine and fisheries sector; (d). Utilization of information technology to expand the range of training services (online training); (e). Development of training networks and empowerment of Marine and Fisheries training graduates; (f). Development of an extension system according to the needs and conditions of the main actors.

5. Development of science and technology innovation. The operational steps that will be carried out are (a). Increase the support of science and technology for increasing product competitiveness and productivity through innovation, mastery of research, and application of science and technology in synergy with education, training, and counseling activities; (b). Increase the role of research as a provider of innovative technology to support the Tri Darma of Higher Education and become material for curriculum module preparation so that it is in line with technological advances, and the use of research and research infrastructure in increasing the capacity of students; (c). Increasing the role of research in the development of a Mobile multimedia-based Smart Fisherman Information System, spatial information systems for fishing areas and environmental changes in coastal ecosystems, and analysis of the potential and vulnerability of coastal resources can be disseminated to the community through the role of fisheries extension agents.

\subsubsection{Institution}

The institutional system is one of the important factors and has a huge influence on the successful implementation of government collaboration in realizing sustainable development. Taking into account the objective conditions and real potential as well as past development experiences, the development agenda is designed as a translation of the implementation of the mission to realize the government's agreed development vision. These interrelated issues require synergistic, coordinated, and focused attention on a careful development agenda. Therefore, the direction of institutional development includes (Renstra KKP, 2019):

a) Gender mainstreaming. Gender mainstreaming in the marine and fisheries sector will be implemented with a strategy of increasing gender roles, access, control, and benefits in the development of KP. The operational steps taken include (1) Implementation of Gender Responsive Planning and Budgeting (PPRG), (2) Strengthening PUG institutions in the KKP, (3) Preparation of PUG roadmap, (4) compilation of disaggregated data, (5) Development of statistics gender, (6) Development of an integrated PUG implementation model between the first echelon units in the KKP and between the central and regional governments.

b) Regional development. Regional development will be implemented with a strategy of accelerating the reduction of development gaps between regions. Operational steps taken include (1) Preparation of regional spatial plans with a Strategic Environmental Assessment (KLHS), (2) Synergy of activities in integrated fisheries areas/centers/Minapolitan/small islands-based community fishery business centers, (3) Increasing government, BUMN/BUMD, and private investment in areas/integrated fisheries centers/Minapolitan/small island-based small-scale fisheries business centers, (4) Deregulation (debottlenecking) of several regulations that hinder investment implementation, (5) Synergy of the division of authority between the central government, provincial governments and district/city governments, (6) Synergy of cross-sector activities. 
c) Climate change adaptation. Climate change adaptation will be implemented with the following strategies:

1) Climate change mitigation and adaptation, operational steps include:

a. Coastal area rehabilitation

b. Implementing environmentally friendly cultural activities, fishing, and marketing processing

c. Fish health management

d. Increasing the capacity of the Fish Pest and Disease (HPI) laboratory

e. Development of superior local specific fish commodities and fish species resistant to environmental changes.

2) Increasing the resilience of the KP community against climate change

The operational steps taken include: (a) Smart fisherman information system, (b) development of a cold chain system from ships (catching and handling fish catch) to TPI and processing units, (c) Development of curriculum and education modules and training on adaptation systems and disaster mitigation and marine pollution prevention, (d) Development of facilities and infrastructure for disaster mitigation and climate change in coastal areas.

d) Good governance. To implement the Good Governance policy direction, strategies, and steps that will be taken, among others:

1) Building a professional work culture, steps that will be taken are (a) Improving the quality and discipline of the apparatus; (b) Development of knowledge management; (c) Provision of reliable statistical data and information; (d) Development of a resultsoriented planning system and structured monitoring and evaluation of performance management; (e) Preparation of harmonious laws and regulations; (f) efficient and accountable budget management; (g) One-stop service-oriented to excellent service; $(\mathrm{h})$ Increase in functional PNBP; (i) International and inter-agency cooperation.

2) Improving the quality of internal supervision, steps that will be taken include: (a) Implementation of the Government Internal Control System (SPIP); (b) Application of a professional and synergistic internal control system; (c) Increasing the effectiveness of the implementation of prevention and anti-corruption policies towards CorruptionFree Areas (WBK) and Clean Serving Bureaucratic Areas (WBBM).

\subsubsection{International Cooperation}

One of Indonesia's involvement in SDGs domestically and internationally is the SouthSouth and Triangle (SSTC). Since the Asia-Africa Conference, Indonesia has actively participated in cooperation with other developing countries. In commemoration of the 50th anniversary of the conference, the government reiterated the importance of cooperation with countries in the southern region with several dimensions. The RPJMN also includes incentive development for government-to-government relations, People to People, and Business to Business under the SSTC. The government also initiated South-South Cooperation (SSC) with UNDP and bilateral partners (Kencono, Dewi Sekar \& EE Supriyanto, 2017).

In 2018, Our Ocean Conference (OOC) event in Bali, there were 6 (six) commitments signed between the KKP and the OOC including Climate Change, Maritime Security, Marine Pollution, Regional Protection Marine (Marine Protected Area), Sustainable Blue Economy (Sustainable blue economy) and Sustainable Fisheries (Sustainable fisheries). Most of the commitments put forward by governments are followed by NGOs and the Corporate Sector, the United Nations, academics, the scientific community, and philanthropic organizations. 
This commitment covers almost all marine fields. Commitments made by Indonesia totaled 23 with total financing of 80 million USD through the World Bank in collaboration with NGOs and several sectors and corporate foundations.

\section{Conclusion}

Any form of sustainable development and its other variants, the main goal is of course for the welfare of the community, especially in this context, not only coastal communities, this nation already has a very principal concept related to welfare since the beginning of this republic was founded, namely the fifth principle of Pancasila. As a Ministry that has the authority to assist the President in managing marine and fisheries, KKP has all the resources with all its strengths and weaknesses. These institutional pillars are the capital to move Indonesia's marine and fisheries sectors to become a symbol of a new world power.

All gaps in the marine and fisheries areas, such as an imbalance in management and lack of protection of marine and coastal ecosystems in several areas as well as massive illegal fishing activities or illegal fishing by neighboring countries, especially inequality in marine infrastructure, of course, there is a need for collaboration in good synergic governance between government and government, government and corporations, and government and society or NGOs. Of course, the positive collaboration will have a significant impact on the future of the Indonesian marine and fisheries world.

\section{Acknowledgment}

The author would like to extend the appreciation to the resource persons who have provided input on this article, as well as discussion partners on campus who inspire collaborative governance in a Ministry. Although this article is not perfect hopefully it will be of benefit to readers.

\section{References}

[1] Al-Khateeb, Mukdad A, Nadhir Al-Ansari, and Sven Knutsson. 2016. "A Spatial Sustainable Development Model Based on Partnership between Government, Community, and Specialist in Baghdad Challenges of Sustainable Development in Iraq, Investment for Sustainable Development, Sustainable Development Capitals, Sustainable Commu." Creative Education Community and Specialist in Baghdad. Creative Education 7 (7): 1881-90.

[2] Benyamin, Lakit \& Nuni Gofar. 2013. "Technology Innovation Policy for Sustainable Suboptimal Land Management." National Seminar on Suboptimal Lands 1 (September): 20-21.

[3] Dewantama, Made Iwan, N K Mardani, and I B Windia Adnyana. 2007. "Study on the Collaborative Management Effectiveness of the Waters of West Bali National Park on Living Coral Cover and the Socio-Economy of Local Communities." Ecotrophic 2 (2): $1-10$.

[4] Eko Priyo Purnomo, Rijal Ramdani, and Ady Muzwardi. Rendra setyadiharja. 2018. Collaborative Governance in Community Based Forest Management.

[5] Gash, Alison. 2016. Handbook on Theories of Governance Collaborative Governance. 
[6] John J. Forrer, James Edwin Kee, Eric Boyer. 2014. 1 Jossey-Bass A Wiley Brand Governing Cross-Sector Collaboration.

[7] Kencono, Dewi Sekar \& EE, Supriyanto (Department of Government Affairs and Administration / UMY). 2017. "Collaborative Governance for Sustainable Development in Indonesia: The Case of the Special Region of Yogyakarta Province." Journal of Government and Politics International Conference 2 (Shifting Dynamic of Social Politics: The Implication for Policy Making and Community Empowerment): 449-64.

[8] Kuhn, Berthold. 2016. "Collaborative Governance for Sustainable Development in China." Open Journal of Political Science 06 (04): 433-53.

[9] Minarti Harahap, Irma, Achmad Fahrudin, and Yusli Wardiatno. 2015. "Collaborative Management of Sea Turtle Pangumbahan Marine Protected Area, Sukabumi District)." Indonesian Journal of Agricultural Sciences (JIPI) 20 (1): 39-46. journal.ipb.ac.id/index.php/JIPI.

[10] Robert Agranoff, Michael McGuire. 2003.1 Georgetown University Press Washington, D.C. Collaborative Public Management. ed. Barry (University of Michigan) Rabe. Wahington, D.C.

[11] Shofwan, Khusaini, Badriah (Faculty of Economics / Brawijaya University). 2008. "Management of Marine Resources Potential as Efforts to Increase Fishermen's Income (Case Study of Coastal Community-Based Management in Tegal Regency)." Journal of Indonesian Applied Economics 2 (1): 102-12.

[12] Sulaiman (Master of Law Science / Diponegoro University). 2010. 9 Diponegoro University "ALTERNATIVE MODEL FOR MANAGEMENT OF FISHERY MANAGEMENT BASED ON LAOT TRADITIONAL LAW IN ACEH JAYA DISTRICT TOWARDS A SUSTAINABLE ENVIRONMENTAL WELFARE ORIENTED COMMUNITY."

[13] SUPRIYANTO, E. E. S. E. E. IMPLEMENTATION OF PANCASILA VALUES IN ECONOMIC POLICIES IN TEGAL DISTRICT 2009-2014. Politics: Journal of Political Science, 4 (1), 80-88.

[14] Sunyowati, Dina. 2010. "Marine Governance Based on Integrated Coastal and Ocean Management for Sustainable Marine Development." Perspective 15 (1): 76.

[15] Ministry of Marine Affairs and Fisheries Strategic Plan 2015-2019 